\title{
Noble metal catalysts for the preferential oxidation of carbon monoxide in the presence of hydrogen (PROX)
}

\author{
Fernando Mariño $^{\mathrm{a}, \mathrm{b}, *}$, Claude Descorme ${ }^{\mathrm{a}, \mathrm{c}}$, Daniel Duprez $^{\mathrm{a}}$ \\ a LACCO-UMR 6503, CNRS-Université de Poitiers, 40 Avenue du Recteur Pineau, F-86022 Poitiers Cedex, France \\ ${ }^{\mathrm{b}}$ Laboratorio de Procesos Catalíticos, DIQ-FIUBA, Universidad de Buenos Aires, Pabellón de Industrias, \\ Ciudad Universitaria, 1428 Buenos Aires, Argentina \\ ${ }^{\mathrm{c}}$ Institut de Recherches sur la Catalyse (IRC), CNRS, 2 Avenue Albert Einstein, F-69626 Villeurbanne Cedex, France
}

\begin{abstract}
Oxide-supported noble metal catalysts were tested in the preferential oxidation of carbon monoxide (PROX) reaction in the temperature range between 50 and $300^{\circ} \mathrm{C}$. Both the influence of the noble metal nature (Pt, Ir, Pd), the support physical and chemical properties (redox, acidity, basicity) and the reaction conditions (oxygen stoichiometry) on the catalyst activity and selectivity was evaluated. Platinum and iridium were shown to be the most active and selective catalysts in the whole temperature range compared with palladium. Furthermore, noble metals supported over ceria-based oxides were shown to be active and selective, especially at low temperature. Additionally, it was observed that the higher the molar fraction in ceria in the oxide, the higher the activity and the selectivity in the PROX reaction. Ceria, with the highest oxygen mobility at the oxide surface, was shown to be the best support. Accordingly, on simple oxides $\left(\mathrm{CeO}_{2}, \mathrm{SiO}_{2}-\mathrm{Al}_{2} \mathrm{O}_{3}, \mathrm{~A}_{2} \mathrm{O}_{3}, \mathrm{SiO}_{2}, \mathrm{~L}_{2} \mathrm{O}_{3}\right.$ and $\mathrm{MgO}$ ), the induced mobility of the oxygen atoms at the surface of the support determined elsewhere, well correlated with the basicity of the support, was shown to be one key parameter for the performances of the catalysts in the PROX reaction. Finally, the formation of water (hydrogen oxidation) at high temperature and high oxygen excess was shown to be responsible for the increasing activity of the catalysts in the conversion of $\mathrm{CO}$ to $\mathrm{CO}_{2}$ via the water gas shift reaction (WGSR).
\end{abstract}

Keywords: Preferential oxidation of CO; PROX; hydrogen purification; Noble metals; Platinum; Iridium; Palladium; Supported catalysts; Acido-basicity; Redox; Oxygen mobility; Fuel cells; WGSR

\section{Introduction}

Proton exchange membrane fuel cells (PEMFC) have been extensively studied in the past decades. Applications in mobile energy sources have been paid an increasing attention. Pure hydrogen is the ideal fuel for such systems. However, mature technologies for a safe and efficient storage of hydrogen on-board of the vehicle are still not commercially available. As an alternative, hydrogen could likely be generated on-board using a reformer. Natural gas, gasoline or alcohols (methanol, ethanol) are the potential hydrogen sources [1].

In any case, hydrogen is produced together with significant amounts of CO. Because of the high sensitivity of the PEMFC anode catalysts towards even traces of $\mathrm{CO}$, tech-

\footnotetext{
* Corresponding author. Tel.: +54 11457632 40; fax: +54114576 3241 .

E-mail address: fernando@di.fcen.uba.ar (F. Mariño).
}

nologies have to be developed to decrease the $\mathrm{CO}$ level, at least below $50 \mathrm{ppm}$ for the state of the art Pt-Ru anodes. After the reformer, $\mathrm{CO}$ is partially converted to $\mathrm{CO}_{2}$ via the water gas shift reaction (WGSR). Since the conversion of $\mathrm{CO}$ is thermodynamically limited to levels of about $0.5-1 \%$, further purification treatments of the hydrogen stream are required.

To achieve high purification levels, several physical and/or chemical methods have been considered. The preferential oxidation of CO (PROX) appears as the most promising approach and the lowest cost technique. Nevertheless, the oxidation of hydrogen competes with the oxidation of carbon monoxide. Consequently, one critical point is to find a catalyst that is both highly active and highly selective towards the oxidation of carbon monoxide to carbon dioxide. The operating temperature should be somewhere in between the low-temperature WGS unit $\left(250-300^{\circ} \mathrm{C}\right)$ and the temperature of the PEMFC $\left(80-100^{\circ} \mathrm{C}\right)$. Finally, such catalyst 
should be able to operate under transient conditions, as the power demand will vary considerably.

Noble metals, which ones are highly active for the oxidation of pure carbon monoxide, were some of the first catalysts to be proposed for the preferential oxidation of carbon monoxide (PROX). Oh and Sinkevitch [2] studied the activity and the selectivity of several catalytic systems based on noble metals. The best results were obtained with alumina-supported $\mathrm{Pt}, \mathrm{Ru}$ and $\mathrm{Rh}$ catalysts.

Platinum catalysts are by far the most extensively studied catalysts [3-6]. Some authors in particular have examined the kinetics and the mechanism of the PROX reaction over $\mathrm{Pt} / \mathrm{Al}_{2} \mathrm{O}_{3}$ catalysts [7-9]. Gold catalysts were also tested for this reaction. In fact, while pure gold is a poor catalyst for most reactions, mainly due to the weak interactions with most adsorbates, several Authors have shown that highly dispersed gold supported on metal oxides was active at low temperatures (even below $0{ }^{\circ} \mathrm{C}$ ) in the $\mathrm{CO}$ oxidation reaction [10-15]. Unfortunately, it was observed that supported gold catalysts deactivate much rapidly than the corresponding platinum catalysts [16].

In the present work, oxide-supported platinum, iridium and palladium catalysts were studied. In fact, $\mathrm{Pt}$, Ir and Pd were shown to be highly active in the $\mathrm{CO}$ oxidation reaction under oxygen lean conditions, upon three-way catalysis [17-19] and we thought that some analogies could be found with the PROX reaction. Ceria and ceria-zirconia supports are traditionally used as supports for three-way catalysts. In fact, such supports were evidenced to behave as oxygen buffers, capable to feed the metal with oxygen under oxygen lean conditions. Ceria-based supports were compared with other metal oxides-based supports. A large variety of supports $\left(\mathrm{CeO}_{2}, \mathrm{Ce}_{x} \mathrm{Zr}_{(1-x)} \mathrm{O}_{2}, \mathrm{SiO}_{2}-\mathrm{Al}_{2} \mathrm{O}_{3}, \mathrm{Al}_{2} \mathrm{O}_{3}, \mathrm{SiO}_{2}\right.$, $\mathrm{La}_{2} \mathrm{O}_{3}$ and $\mathrm{MgO}$ ), with different redox, acidic and basic properties, were investigated. One of the main purposes of the present study was to understand what could be the role of the different functions on the catalysts, especially the support.

\section{Methods}

\subsection{Catalysts}

Noble metal (Pt, Pd, Ir) catalysts supported over ceria or ceria-zirconia were first prepared and characterized before testing in the preferential oxidation of $\mathrm{CO}$. The preparation conditions were adjusted in order to optimize the metal dispersion $[17,18]$.

The first series of catalysts consisted in ceria-zirconiasupported Pt, Pd and Ir catalysts. Rhodia Electronics and Catalysis (La Rochelle, France) provided us with the supports. These supports were pre-calcined at $900{ }^{\circ} \mathrm{C}$ for $6 \mathrm{~h}$. For comparison purposes, the metal loading was fixed at about $100 \mu \mathrm{m}$ of metal atoms per gram of catalyst, that is 1 wt.\% for Pd and 2 wt.\% for Pt and Ir.
Platinum and palladium catalysts were prepared by wet impregnation of the supports with aqueous solutions of $\mathrm{Pt}\left(\mathrm{NH}_{3}\right)_{4}(\mathrm{OH})_{2}$ and $\mathrm{Pd}\left(\mathrm{NO}_{3}\right)_{3}$, respectively. After impregnation, the samples were dried overnight at $120^{\circ} \mathrm{C}$ and finally calcined in flowing dry air $\left(30 \mathrm{~mL} \mathrm{~min}^{-1}\right)$ at $500^{\circ} \mathrm{C}$ for $4 \mathrm{~h}$.

In the case of iridium, the catalysts prepared by classical impregnation had shown very poor metal dispersions [20]. For that reason, the iridium catalysts under study were prepared by impregnation in an ultrasonic bath using an acetone solution of $\operatorname{Ir}\left[\mathrm{CH}\left(\mathrm{COCH}_{3}\right)_{2}\right]_{3}$. The samples were further dried overnight at $120^{\circ} \mathrm{C}$ and reduced in flowing hydrogen $\left(30 \mathrm{~mL} \mathrm{~min}^{-1}\right)$ at $500^{\circ} \mathrm{C}$ for $4 \mathrm{~h}$.

The second series of supported catalysts was prepared with a nominal platinum content of about $3 \mathrm{wt} . \%$. Several oxide supports were tested with very different redox, acidic and basic properties $\left(\mathrm{CeO}_{2}, \mathrm{SiO}_{2}-\mathrm{Al}_{2} \mathrm{O}_{3}, \mathrm{Al}_{2} \mathrm{O}_{3}, \mathrm{SiO}_{2}, \mathrm{La}_{2} \mathrm{O}_{3}\right.$ and $\mathrm{MgO}$ ).

The samples were prepared by classical wet impregnation of the supports with a $\mathrm{Pt}\left(\mathrm{NH}_{3}\right)_{4}(\mathrm{OH})_{2}$ solution at $\mathrm{pH} 11$, dried overnight at $120^{\circ} \mathrm{C}$, treated in flowing dry air at $450^{\circ} \mathrm{C}$ four $4 \mathrm{~h}$ and finally reduced in hydrogen at $500^{\circ} \mathrm{C}$ for $8 \mathrm{~h}$.

A summary of the physical and chemical characteristics of the supports and the catalysts we prepared in the present study is given in Table 1 .

\subsection{Characterization}

Specific surface areas $\left(S_{\mathrm{BET}}\right.$ expressed in $\left.\mathrm{m}^{2} \mathrm{~g}^{-1}\right)$ were measured by $\mathrm{N}_{2}$ adsorption at $-196^{\circ} \mathrm{C}$ on a Micromeritics Flowsorb II apparatus. For seek of rapidity, the single point method was selected. Before the measurement, the sample was first outgassed under $\mathrm{He} / \mathrm{N}_{2}$ at $350{ }^{\circ} \mathrm{C}$ for $2 \mathrm{~h}$.

Metal dispersions $\left(D_{\mathrm{M}}\right)$ were derived from $\mathrm{H}_{2}$ chemisorption measurements carried out in a homemade apparatus

Table 1

Characteristics of the supports and catalysts

\begin{tabular}{|c|c|c|c|}
\hline Support & $S_{\text {BET }}\left(\mathrm{m}^{2} \mathrm{~g}^{-1}\right)$ & Catalysts & $D_{\mathrm{M}}(\%)$ \\
\hline $\mathrm{Ce}_{0.15} \mathrm{Zr}_{0.85} \mathrm{O}_{2}$ & 27 & $\begin{array}{l}2 \% \mathrm{Ir} / \mathrm{Ce}_{0.15} \mathrm{Zr}_{0.85} \mathrm{O}_{2} \\
2 \% \mathrm{Pt} / \mathrm{Ce}_{0.15} \mathrm{Zr}_{0.85} \mathrm{O}_{2}\end{array}$ & $\begin{array}{l}- \\
-\end{array}$ \\
\hline $\mathrm{Ce}_{0.5} \mathrm{Zr}_{0.5} \mathrm{O}_{2}$ & 45 & $\begin{array}{l}2 \% \mathrm{Ir} / \mathrm{Ce}_{0.5} \mathrm{Zr}_{0.5} \mathrm{O}_{2} \\
2 \% \mathrm{Pt} / \mathrm{Ce}_{0.5} \mathrm{Zr}_{0.5} \mathrm{O}_{2}\end{array}$ & $\begin{array}{l}- \\
-\end{array}$ \\
\hline $\mathrm{Ce}_{0.63} \mathrm{Zr}_{0.37} \mathrm{O}_{2}$ & 43 & $\begin{array}{l}2 \% \mathrm{Ir} / \mathrm{Ce}_{0.63} \mathrm{Zr}_{0.37} \mathrm{O}_{2} \\
1 \% \mathrm{Pd} / \mathrm{Ce}_{0.63} \mathrm{Zr}_{0.37} \mathrm{O}_{2} \\
2 \% \mathrm{Pt} / \mathrm{Ce}_{0.63} \mathrm{Zr}_{0.37} \mathrm{O}_{2}\end{array}$ & $\begin{array}{l}29^{\mathrm{a}} \\
61^{\mathrm{a}} \\
78^{\mathrm{a}}\end{array}$ \\
\hline $\mathrm{CeO}_{2}$ & 25 & $\begin{array}{l}2 \% \mathrm{Ir} / \mathrm{CeO}_{2} \\
2 \% \mathrm{Pt} / \mathrm{CeO}_{2} \\
3 \% \mathrm{Pt} / \mathrm{CeO}_{2}\end{array}$ & $\begin{array}{l}38^{\mathrm{a}} \\
79^{\mathrm{a}} \\
33\end{array}$ \\
\hline $\mathrm{MgO}$ & 66 & $3 \% \mathrm{Pt} / \mathrm{MgO}$ & 13 \\
\hline $\mathrm{La}_{2} \mathrm{O}_{3}$ & $\approx 2$ & $3 \% \mathrm{Pt} / \mathrm{La}_{2} \mathrm{O}_{3}$ & 8 \\
\hline $\mathrm{SiO}_{2}$ & 175 & $3 \% \mathrm{Pt} / \mathrm{SiO}_{2}$ & 22 \\
\hline $\mathrm{Al}_{2} \mathrm{O}_{3}$ & 215 & $3 \% \mathrm{Pt} / \mathrm{Al}_{2} \mathrm{O}_{3}$ & 37 \\
\hline $\mathrm{SiO}_{2}-\mathrm{Al}_{2} \mathrm{O}_{3}$ & 525 & $3 \% \mathrm{Pt} / \mathrm{SiO}_{2}-\mathrm{Al}_{2} \mathrm{O}_{3}$ & 53 \\
\hline
\end{tabular}

${ }^{\text {a }}$ Results previously obtained by Bedrane et al. [18]. 
described elsewhere [21]. The samples were first reduced under pure hydrogen $\left(30 \mathrm{~mL} \mathrm{~min}^{-1}\right)$ at $400{ }^{\circ} \mathrm{C}$ for $1 \mathrm{~h}$ and further outgassed under $\operatorname{argon}\left(30 \mathrm{~mL} \mathrm{~min}^{-1}\right)$ for $3 \mathrm{~h}$ at the same temperature. $\mathrm{H}_{2}$ chemisorption was performed at $-85^{\circ} \mathrm{C}$ following an optimized procedure earlier described in details [22]. In fact, one critical point was to avoid any hydrogen spillover onto the support, especially in the case of ceria-based supports.

Both the specific surface areas $\left(S_{\mathrm{BET}}\right)$ of the supports and the metallic dispersion of the catalysts are reported in Table 1.

\subsection{Reactor setup and calculations}

Catalytic tests were carried out in an atmospheric continuous flow reactor. Tubing and connections were made from stainless steal. The catalyst was introduced in a glass fixed bed reactor placed in an electrical oven. Prior to the reaction, the catalysts were preconditioned in situ in flowing air $\left(100 \mathrm{~N} \mathrm{ml} \mathrm{min}^{-1}\right)$ at $300^{\circ} \mathrm{C}$ for $30 \mathrm{~min}$. About $100 \mathrm{mg}$ of catalyst was used for each run. Because of the small size of the catalyst bed ( $8 \mathrm{~mm}$ in diameter and $4 \mathrm{~mm}$ in height), it was assumed that there was no significant temperature profile in the bed. Nevertheless, in a few selected experiments the temperatures at the top and bottom of the bed were measured to confirm the absence of temperature profile.

Analytical grade cylinders (Alphagas-1 from Air Liquide) of hydrogen, nitrogen, $\mathrm{CO}$ and $\mathrm{O}_{2}$ were used. The inlet gas flow rates were controlled using BROOKS mass flow controllers previously calibrated for each specific gas. In a typical experiment, the total inlet gas flow rate was fixed at $100 \mathrm{~N} \mathrm{ml} \mathrm{min}{ }^{-1}$. The reaction mixture consisted in $70 \% \mathrm{H}_{2}$, $2 \% \mathrm{CO}(20000 \mathrm{ppm}), 1-4 \% \mathrm{O}_{2}$ and $\mathrm{N}_{2}$ as a balance. The oxygen excess, $\lambda$, could vary from 1 (stoichiometric) to 4 .

During the reaction, the reactor temperature was progressively ramped from 50 to $300{ }^{\circ} \mathrm{C}$ at a rate of $1{ }^{\circ} \mathrm{C} \mathrm{min}^{-1}$ using a temperature controller. A restricted number of steady-state experiments carried out at a few fixed temperatures $(100$, 150 and $200{ }^{\circ} \mathrm{C}$ ) could verify that the conversions and the selectivities measured under temperature programmed experiments were the same as the steady-state values. Then, the equilibrium seems to be reached instantaneously.

At the reactor outlet, the product analysis was performed using a combination of two gas chromatographs. One chromatograph was equipped with a CTR column and helium was used as the carrier gas while the other chromatograph was equipped with a $5 \AA$ molecular sieve filled column and nitrogen was used as the carrier gas. The second one was used to determine the $\mathrm{H}_{2}$ concentration in the outlet gases. In both cases, TCD detectors were used. Finally, for the concentrations in carbon monoxide below $2000 \mathrm{ppm}$ a specific infrared spectrometer could be used. Only $\mathrm{CO}_{2}$ and $\mathrm{H}_{2} \mathrm{O}$ were detected as the reaction products and $\mathrm{CO}_{2}$ production is in good agreement with $\mathrm{CO}$ consumption. Therefore, we concluded that the conversion of $\mathrm{CO}$ and/or $\mathrm{CO}_{2}$ to $\mathrm{CH}_{4}$ in the presence of large excess of hydrogen (methanation) do not take place under the selected reaction conditions over the catalysts under study.

The oxygen and the carbon monoxide conversions were classically defined as follows:

$$
\begin{aligned}
& x_{\mathrm{O}_{2}}=\frac{F_{\mathrm{O}_{2}}^{\text {in }}-F_{\mathrm{O}_{2}}^{\text {out }}}{F_{\mathrm{O}_{2}}^{\text {in }}} \\
& x_{\mathrm{CO}}=\frac{F_{\mathrm{CO}}^{\text {in }}-F_{\mathrm{CO}}^{\text {out }}}{F_{\mathrm{CO}}^{\text {in }}}
\end{aligned}
$$

where $F_{i}^{\text {in }}$ and $F_{i}^{\text {out }}$ are the inlet and outlet molar flows of gas $i$, respectively.

The selectivity towards $\mathrm{CO}_{2}$ was calculated as the ratio of the desired reaction ( $\mathrm{CO}$ oxidation) to the overall $\mathrm{O}_{2}$ consumption:

$S_{\mathrm{CO}_{2}}=\frac{F_{\mathrm{CO}_{2}}^{\text {out }}}{2\left(F_{\mathrm{O}_{2}}^{\text {in }}-F_{\mathrm{O}_{2}}^{\text {out }}\right)}$

It must be mentioned that the product of the oxygen conversion $\left(x_{\mathrm{O}_{2}}\right)$ by the selectivity towards $\mathrm{CO}_{2}\left(S_{\mathrm{CO}_{2}}\right)$ does not directly result in the $\mathrm{CO}$ conversion. In fact, for $\lambda>1$, the oxygen excess $\left(\lambda=2 F_{\mathrm{O}_{2}}^{\mathrm{in}} / F_{\mathrm{CO}_{2}}^{\mathrm{in}}\right)$ must be taken into account:

$x_{\mathrm{CO}}=x_{\mathrm{O}_{2}} S_{\mathrm{CO}_{2}} \lambda$

\section{Results}

\subsection{Influence of the metal nature}

The results we obtained over $\mathrm{M} / \mathrm{Ce}_{0.63} \mathrm{Zr}_{0.37} \mathrm{O}_{2}$ catalysts $(\mathrm{M}=\mathrm{Pt}, \mathrm{Ir}, \mathrm{Pd})$ are presented in Fig. 1. Ceria-zirconia-supported platinum and iridium catalysts showed a similar behavior. The same trends were observed for both catalysts and a maximum appeared at about $100^{\circ} \mathrm{C}$ in the evolution of the $\mathrm{CO}$ conversion as a function of temperature. Complete oxygen conversion was reached at ca. $100^{\circ} \mathrm{C}$ in the case of platinum and ca. $130^{\circ} \mathrm{C}$ in the case of iridium. Above these temperatures, the selectivity towards the $\mathrm{CO}$ oxidation reaction decreases continuously as the temperature increases. Consequently, the maximum selectivity was observed at the lowest temperature. In fact, ceria-zirconia supports are well-known reducible oxides, highly active for the oxygen storage [22,23]. This specific property of these oxides could explain the high activity and selectivity of these samples, especially at much lower temperatures compared to alumina-supported noble metal catalysts [2,7-9].

At temperatures higher than $175^{\circ} \mathrm{C}$, the $\mathrm{CO}$ conversion increases once again due to the incidence of the WGSR. This effect is more noticeable for the iridium catalyst. For the platinum catalysts, this result can be more readily observed at higher $\lambda$ values (as it will be presented in Fig. 3).

On the contrary, palladium showed a very poor activity in the $\mathrm{CO}$ oxidation reaction. However, the oxygen conversion 

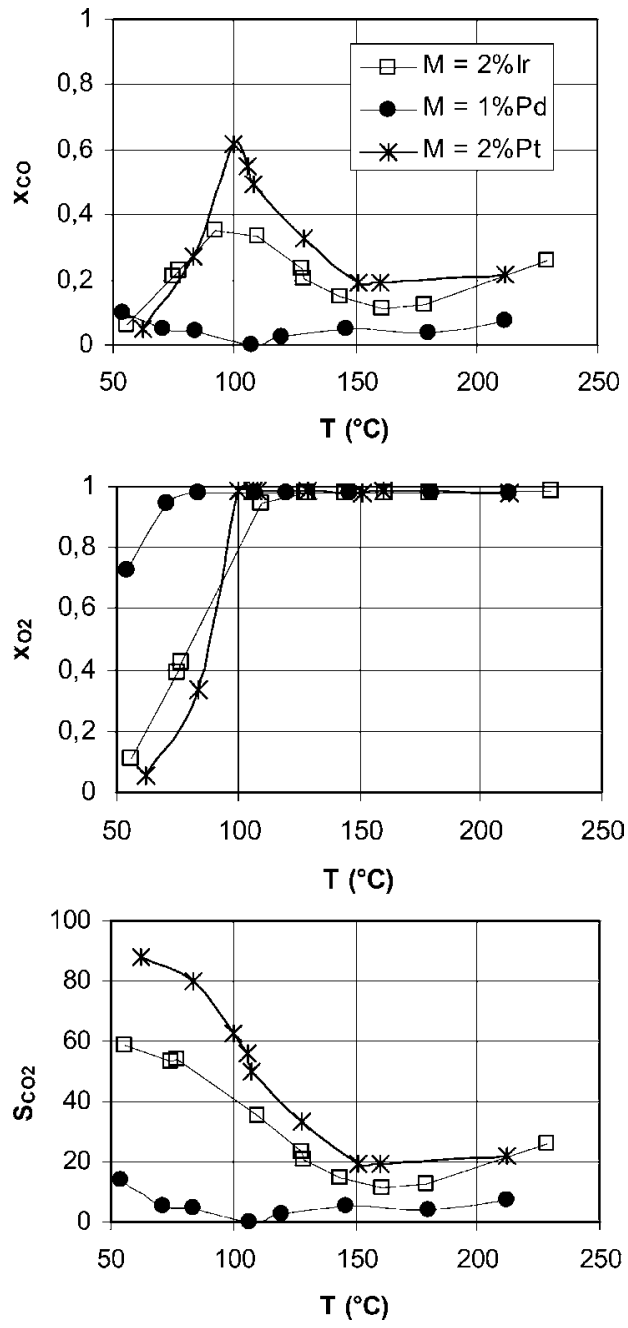

Fig. 1. $\mathrm{CO}$ preferential oxidation on $2 \% \mathrm{Ir} / \mathrm{Ce}_{0.63} \mathrm{Zr}_{0.37} \mathrm{O}_{2}$, $1 \% \mathrm{Pd} / \mathrm{Ce}_{0.63} \mathrm{Zr}_{0.37} \mathrm{O}_{2}$, and $2 \% \mathrm{Pt} / \mathrm{Ce}_{0.63} \mathrm{Zr}_{0.37} \mathrm{O}_{2}$ catalysts. $\mathrm{CO}$ conversion, $\mathrm{O}_{2}$ conversion and $\mathrm{CO}_{2}$ selectivity as a function of reaction temperature. Mass of catalysts: $100 \mathrm{mg}$; total flow: $100 \mathrm{~N} \mathrm{ml} \mathrm{min}^{-1}$; and flow composition: $70 \% \mathrm{H}_{2}, 27 \% \mathrm{~N}_{2}, 2 \% \mathrm{CO}, 1 \% \mathrm{O}_{2}(\lambda=1)$.

on $1 \% \mathrm{Pd} / \mathrm{Ce}_{0.63} \mathrm{Zr}_{0.37} \mathrm{O}_{2}$ was even higher at low temperature compared to the corresponding Pt and Ir catalysts. In fact, the hydrogen oxidation appeared to be greatly favored. As a result, the selectivity towards $\mathrm{CO}_{2}$ formation was very low. For that reason, we did not continue with palladium as the active phase.

\subsection{Influence of the mixed oxide composition in $\mathrm{Ce}_{x} \mathrm{Zr}_{(1-x)} \mathrm{O}_{2}$ supports}

After the selection of the most active noble metals, the influence of the composition of the mixed oxide phase was investigated. The activity and the selectivity of platinum and iridium catalysts supported on $\mathrm{Ce}_{x} \mathrm{Zr}_{(1-x)} \mathrm{O}_{2}(x=0.15,0.5$, 1) are presented in Fig. 2. One can observe that both the conversion of $\mathrm{CO}$ and the selectivity towards $\mathrm{CO}_{2}$ formation increase as the atomic fraction in cerium $(x)$ in the mixed oxide increases.

\subsection{Influence of the oxygen excess $(\lambda)$}

To go further, the influence of the gas phase composition was checked, especially the oxygen excess $(\lambda)$. Though all the platinum and iridium catalysts tested present a similar behavior, Fig. 3 shows the results obtained with samples $2 \% \mathrm{Pt} / \mathrm{Ce}_{0.15} \mathrm{Zr}_{0.85} \mathrm{O}_{2}$ and $2 \% \mathrm{Ir} / \mathrm{Ce}_{0.15} \mathrm{Zr}_{0.85} \mathrm{O}_{2}$, for which the trend seems to be more marked.

In the two cases, both the $\mathrm{CO}$ and $\mathrm{H}_{2}$ oxidation increase as $\lambda$ increase. However, the effect of the oxygen excess is much more pronounced on the hydrogen oxidation. As a result, the selectivity towards $\mathrm{CO}_{2}$ formation decreases as the oxygen excess increases. This result is in agreement with the results obtained on a $\mathrm{Pt} / \mathrm{Al}_{2} \mathrm{O}_{3}$ catalyst [24]. In both cases $\left(\mathrm{Pt} / \mathrm{Al}_{2} \mathrm{O}_{3}\right.$ and $\left.\mathrm{Pt} / \mathrm{CeO}_{2}\right)$, platinum has showed a natural selectivity towards $\mathrm{CO}$ oxidation as lower $\lambda$ values resulted in higher selectivities.

Above $175^{\circ} \mathrm{C}$, the conversion of $\mathrm{CO}$ and the selectivity towards the formation of $\mathrm{CO}_{2}$ increase once again for both platinum and iridium catalysts. The water gas shift reaction (WGSR) was thought to be responsible for this phenomenon. In fact, Barbier et al. [25] studied a series of $\mathrm{Pt} / \mathrm{Al}_{2} \mathrm{O}_{3}$ catalysts doped with ceria. The authors found that platinum was very active in the conversion of $\mathrm{CO}$ to $\mathrm{CO}_{2}$ at relatively low temperature as they used an $\mathrm{O}_{2} / \mathrm{CO} / \mathrm{H}_{2} \mathrm{O}$ mixture. The authors concluded that the $\mathrm{CO}$ oxidation occurs together with the WGSR. The authors also observed that ceria strongly enhances the WGSR activity of the catalyst. Whereas Ir deposited on alumina is not very active in WGSR [26], it seems here much more active when deposited on ceria-zirconia, in accordance with the promoter role of ceria or ceria-zirconia in this reaction.

The WGS reaction is favored by the high $\lambda$ values. This effect can be simply explained by the fact that the higher the oxygen concentration, the faster the hydrogen oxidation. As a result, more water is formed and the WGSR is strongly favored.

\subsection{Influence of the acid-base properties of the supports}

The role of the support was tentatively confirmed using a larger variety of oxides $\left(\mathrm{CeO}_{2}, \mathrm{SiO}_{2}-\mathrm{Al}_{2} \mathrm{O}_{3}, \mathrm{Al}_{2} \mathrm{O}_{3}\right.$, $\mathrm{SiO}_{2}, \mathrm{La}_{2} \mathrm{O}_{3}$ and $\mathrm{MgO}$ ). As one can see, both acidic and basic supports were selected in addition/combination to/with reducible oxides. The effect of the support was examined through the evaluation of a series of $3 \mathrm{wt} . \%$ platinum catalysts.

Hydrogen chemisorption measurements carried out at $-85^{\circ} \mathrm{C}$ showed that platinum is better dispersed on the acidic supports (see Table 1). However, as one can see from Fig. 4, the samples prepared on basic supports were more active for the $\mathrm{CO}$ oxidation reaction than the corresponding samples supported on acidic ones. The ability of the catalyst to convert $\mathrm{CO}$ appeared to be somehow correlated with the ability of the catalyst to activate the oxygen. In fact, some kind of parallel does exist between 

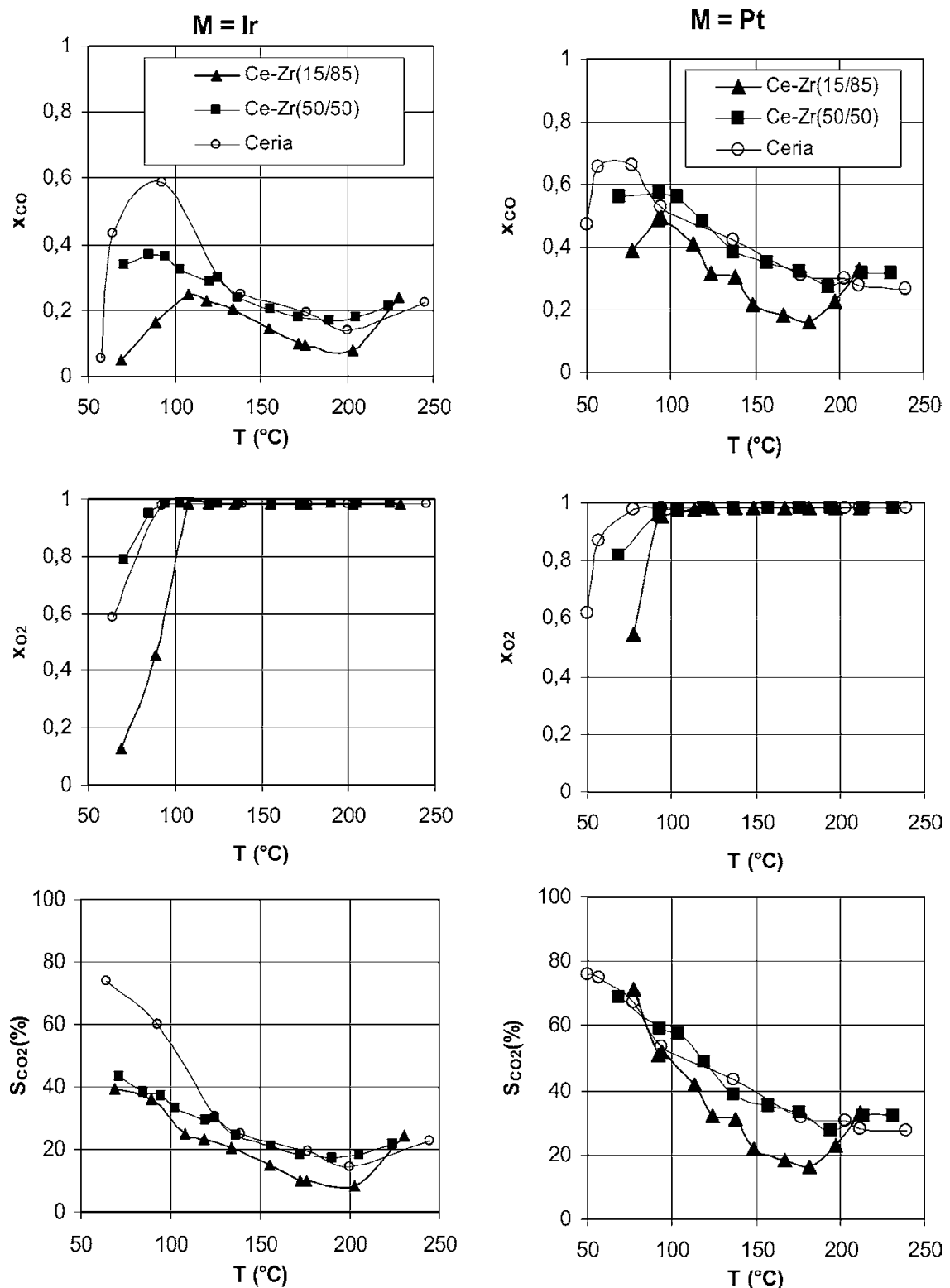

Fig. 2. $\mathrm{CO}$ preferential oxidation on $2 \% \mathrm{M} /$ support catalysts. $\mathrm{M}$ : Ir, Pt. Supports: $\mathrm{Ce}_{0.15} \mathrm{Zr}_{0.85} \mathrm{O}_{2}(\boldsymbol{\Delta}), \mathrm{Ce}_{0.50} \mathrm{Zr}_{0.50} \mathrm{O}_{2}(\boldsymbol{\square})$, CeO $\mathrm{O}_{2}\left(\mathrm{O}_{\text {). }} \mathrm{CO}\right.$ conversion, $\mathrm{O}_{2}$ conversion and $\mathrm{CO}_{2}$ selectivity as a function of reaction temperature. Mass of catalysts: $100 \mathrm{mg}$; total flow: $100 \mathrm{Nml}$ min ${ }^{-1}$; and flow composition: $70 \% \mathrm{H}_{2}, 27 \% \mathrm{~N}_{2}, 2 \% \mathrm{CO}, 1 \% \mathrm{O}_{2}(\lambda=1)$.

the evolution of the $\mathrm{CO}$ conversion and the oxygen consumption.

The $3 \% \mathrm{Pt} / \mathrm{CeO}_{2}$ catalyst showed in Fig. 4 behaves in a completely different way compared to the other oxides and similarly to $2 \% \mathrm{Pt} / \mathrm{CeO}_{2}$ in Fig. 2. Such a specific behavior that could be attributed to the redox properties of ceria is not affected whatever the metal loading or the metal dispersion are.

\section{Discussion}

Among the noble metals we studied, both platinum and iridium catalysts were shown to be active in the oxidation of carbon monoxide in the presence of large excess in hydrogen $\left(70 \% \mathrm{H}_{2}, 2 \% \mathrm{CO}, 1-4 \% \mathrm{O}_{2}\right.$ and $\mathrm{N}_{2}$ as a balance). Nevertheless, platinum appeared as the best. High activities were measured even at low temperatures $\left(T<100^{\circ} \mathrm{C}\right)$.

Unfortunately, noble metals may adsorb all the reactants involved in the $\mathrm{CO}$ preferential oxidation $\left(\mathrm{CO}, \mathrm{H}_{2}, \mathrm{O}_{2}\right)$. As a result, the undesired hydrogen oxidation reaction also proceeds in competition with the oxidation of CO. In fact, as the reaction temperature increases the hydrogen oxidation becomes faster than the $\mathrm{CO}$ oxidation reaction and, at some point, a decrease of the selectivity towards $\mathrm{CO}_{2}$ formation was systematically observed. Furthermore, since the oxygen activation takes place easily on these metals, the hydrogen oxidation rate is also accelerated when the oxygen 

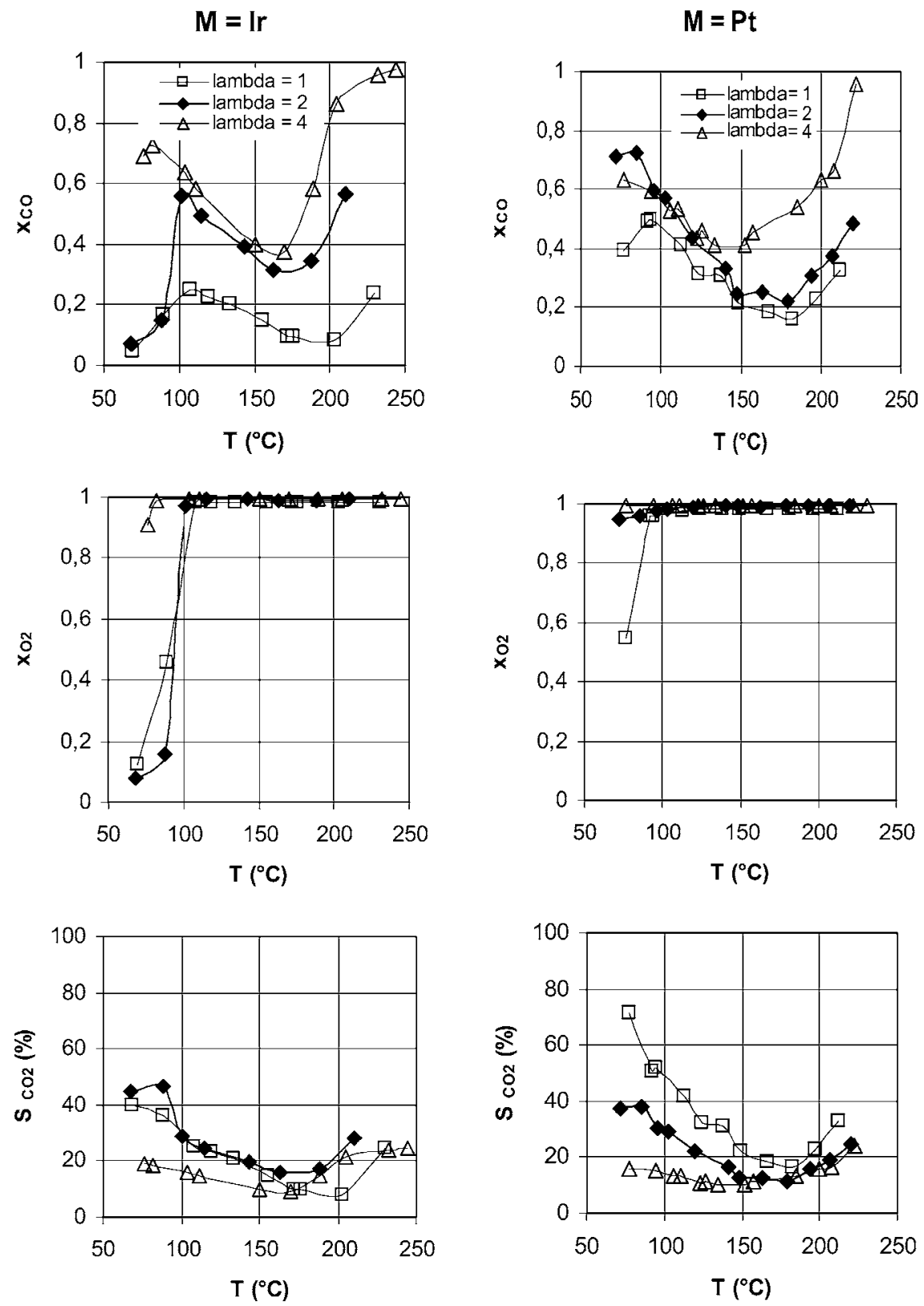

Fig. 3. $\mathrm{CO}$ preferential oxidation on $2 \% \mathrm{M} / \mathrm{Ce}_{0.15} \mathrm{Zr}_{0.85} \mathrm{O}_{2}$ catalysts. $\mathrm{M}$ : $\mathrm{Ir}$, Pt. CO conversion, $\mathrm{O}_{2}$ conversion and $\mathrm{CO}_{2}$ selectivity as a function of reaction temperature and oxygen excess $(\lambda)$. Mass of catalysts: $100 \mathrm{mg}$; total flow: $100 \mathrm{~N} \mathrm{ml} \mathrm{min}^{-1} ;$ and flow composition: $70 \% \mathrm{H}_{2}, 2 \% \mathrm{CO}, 1-4 \% \mathrm{O}_{2}(\lambda=1-4)$, and rest $\mathrm{N}_{2}$.

concentration in the feed increases. In other words, the selectivity loss is more pronounced at high $\lambda$ values.

In contrast, some very bad results were obtained with palladium catalysts. The heat of formation of palladium oxide, which is low compared to the rest of the noble metals, could justify this atypical behavior. In fact, above $60^{\circ} \mathrm{C}$, the palladium starts to oxidize to palladium oxide ( $\mathrm{PdO})$, which one is practically inactive for the PROX reaction [2]. For that reason, palladium was discarded as we looked forward for the optimum catalytic formulation.

As we have seen, the support has a real impact on the performances of the catalysts in the preferential oxidation of
CO. For platinum catalysts, a completely different picture could be drawn depending if we looked at a reducible support, active for oxygen storage such as $\mathrm{CeO}_{2}$ or at the other "classical" oxides (Fig. 4). Furthermore, as we studied the mixed oxide phase composition, we observed that the less active catalysts were the one supported on oxides with the higher concentration in zirconium (Fig. 2). This could be explained by the fact that zirconium oxide is not an active support for the surface oxygen mobility.

In the case of the catalysts supported on "non-active" supports, such as $\mathrm{Al}_{2} \mathrm{O}_{3}$, the $\mathrm{CO}$ preferential oxidation (PROX) was historically described using competitive 

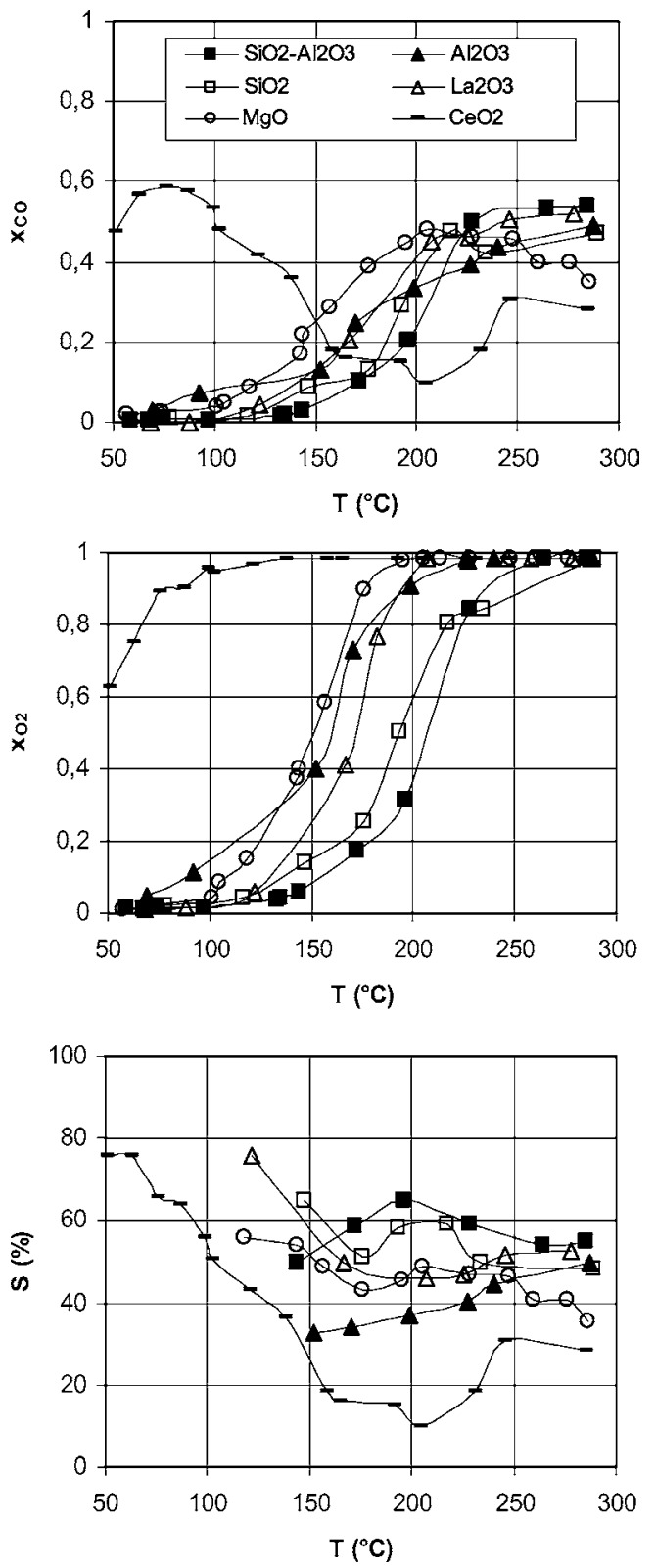

Fig. 4. $\mathrm{CO}$ preferential oxidation on $3 \% \mathrm{Pt} / \mathrm{support}$ catalysts. Supports: $\mathrm{SiO}_{2}-\mathrm{Al}_{2} \mathrm{O}_{3}(\boldsymbol{\square}), \mathrm{Al}_{2} \mathrm{O}_{3}(\mathbf{\Delta}), \mathrm{SiO}_{2}(\square), \mathrm{La}_{2} \mathrm{O}_{3}(\triangle), \mathrm{MgO}(\bigcirc), \mathrm{CeO}_{2}(-)$. $\mathrm{CO}$ conversion, $\mathrm{O}_{2}$ conversion and $\mathrm{CO}_{2}$ selectivity as a function of reaction temperature. Mass of catalysts: $100 \mathrm{mg}$; total flow: $100 \mathrm{~N} \mathrm{ml} \mathrm{min}^{-1}$; and flow composition: $70 \% \mathrm{H}_{2}, 27 \% \mathrm{~N}_{2}, 2 \% \mathrm{CO}, 1 \% \mathrm{O}_{2}(\lambda=1)$.

Langmuir-Hinshelwood kinetics. However, from all what we have seen above, it can be postulated that a different reaction mechanism applies in the case of the catalysts supported on reducible oxides. Other authors $[27,28]$ have shown that surface oxygen atoms from ceria do participate in the oxidation of $\mathrm{CO}$ at low temperature. Accordingly, we proposed that the preferential oxidation of $\mathrm{CO}$ over ceria-supported catalysts could occur via a non-competitive Langmuir-Hinshelwood mechanism. Such a mechanism should involve the reaction between the $\mathrm{CO}$ adsorbed on the noble metal (Pt or Ir) particles and the oxygen atoms previously activated on the support. Such a mechanism was previously reported for Fe-oxide promoted Pt/alumina catalysts [29].

Finally, we observed from Fig. 4 that the oxygen conversion on the different catalysts varies as follows: $\mathrm{CeO}_{2}$ $>\mathrm{Al}_{2} \mathrm{O}_{3}>\mathrm{MgO}>\mathrm{La}_{2} \mathrm{O}_{3}>\mathrm{SiO}_{2}>\mathrm{SiO}_{2}-\mathrm{Al}_{2} \mathrm{O}_{3}$. If one excludes the alumina-supported catalyst, this classification does perfectly match the basicity scale for these oxides [30]. Furthermore, a correlation between the oxygen surface diffusion coefficient and the basicity of these oxides had been already reported [31]. Alumina was again an exception and the oxygen mobility, in comparison, was much higher than it would have been expected from the basicity of this oxide. Consequently, the oxygen mobility on the oxide support appears to have a major impact on the catalyst performances in the PROX reaction.

\section{Conclusions}

Ceria-based supported platinum or iridium catalysts were shown to be suitable for the removal of $\mathrm{CO}$ in the presence of large quantities of hydrogen via the preferential oxidation of CO. Further work must be performed to evaluate the performance and stability of these samples in the presence of water and/or $\mathrm{CO}_{2}$.

The optimum performances were obtained at low temperatures $\left(T<100^{\circ} \mathrm{C}\right)$. In fact, at higher temperature the hydrogen oxidation also takes place and the selectivity towards the formation of $\mathrm{CO}_{2}$ markedly decreases.

However, even at low temperature, the $\mathrm{CO}$ oxidation activity was still not high enough to achieve the low $\mathrm{CO}$ levels acceptable to operate a fuel cell, at least after a single step PROX reactor. The best $\mathrm{CO}$ overall removal level was obtained on $\mathrm{Pt} / \mathrm{Ce}_{0.15} \mathrm{Zr}_{0.85} \mathrm{O}_{2}$ at $225^{\circ} \mathrm{C}$ and $\lambda=4$. Under such reaction conditions, the $\mathrm{CO}$ concentration in the outlet feed was reduced down to approximately $700 \mathrm{ppm}$ via the simultaneous PROX and WGS reactions.

\section{Acknowledgements}

The French Ministry of Research and New Technologies is gratefully acknowledged for financially supporting Dr. Fernando Mariño's post-doctoral stay in France.

\section{References}

[1] F. Auprêtre, C. Descorme, D. Duprez, Catal. Commun. 3 (2002) 263.

[2] S. Oh, R. Sinkevitch, J. Catal. 142 (1993) 254.

[3] O. Korotkikh, R. Farrauto, Catal. Today 62 (2000) 249.

[4] H. Igarashi, H. Uchida, M. Suzuki, Y. Sasaki, M. Watanabe, Appl. Catal. 159 (1997) 159.

[5] A. Manasilp, E. Gulari, Appl. Catal. B: Environ. 37 (2002) 17.

[6] I. Son, M. Shamsuzzoha, M. Lane, J. Catal. 210 (2002) 460.

[7] M. Kahlich, H. Gasteiger, R. Behm, J. Catal. 171 (1997) 93. 
[8] Y. Han, M. Kahlich, M. Kne, R. Behm, PCCP 4 (2002) 389.

[9] H. Kim, M. Lim, Appl. Catal. A: Gen. 224 (2002) 27.

[10] M. Haruta, Catal. Today 36 (1997) 153.

[11] M. Kahlich, H. Gasteiger, R. Behm, J. Catal. 182 (1999) 430.

[12] G. Bethke, H. Kung, Appl. Catal. A: Gen. 194 (2000) 43.

[13] M. Bollinger, M. Vannice, Appl. Catal. B: Environ. 85 (1996) 417.

[14] G. Avgouropoulos, T. Ioannides, Ch. Papadopoulou, J. Batista, S. Hocevar, H. Matralis, Catal. Today 75 (2002) 157.

[15] R. Grisel, B. Nieuwenhuys, J. Catal. 199 (2001) 48.

[16] M. Schubert, M. Kahlich, H. Gasteiger, R. Behm, J. Power Sources 84 (1999) 175.

[17] S. Bedrane, C. Descorme, D. Duprez, Catal. Today 73 (2002) 233.

[18] S. Bedrane, C. Descorme, D. Duprez, Catal. Today 75 (2002) 401.

[19] E. Bekyarova, P. Fornasiero, J. Kaspar, M. Graziani, Catal. Today 45 (1998) 179.

[20] S. Bedrane, C. Descorme, D. Duprez, J. Mater. Chem. 12 (5) (2002) 1563.
[21] S. Kacimi, J. Barbier Jr., R. Taha, D. Duprez, Catal. Lett. 22 (1993) 343.

[22] Y. Madier, Ph.D. Thesis, Poitiers University, 1999.

[23] Y. Madier, C. Descorme, A. Le Govic, D. Duprez, J. Phys. Chem. B. 103 (1999) 10999.

[24] A. Woostch, C. Descorme, D. Duprez, J. Catal. 225 (2) (2004) 259.

[25] J. Barbier Jr., D. Duprez, Appl. Catal. B: Environ. 3 (1993) 61.

[26] D. Grenoble, M. Estadt, D. Ollis, J. Catal. 67 (1981) 90.

[27] T. Bunluesin, G. Graham, R. Gorte, Appl. Catal. B: Environ. 14 (1997) 105

[28] R. Taha, D. Martin, S. Kacimi, D. Duprez, Catal. Today 29 (1996) 89.

[29] X. Liu, O. Korotkikh, R. Farrauto, Appl. Catal. A: Gen. 226 (2002) 460.

[30] D. Martin, D. Duprez, J. Phys. Chem. 100 (1996) 9429.

[31] D. Martin, Ph.D. Thesis, Poitiers University, 1994 